\title{
Introduction: new ethical fields and the implicitness/ explicitness of ethics in Africa
}

\author{
Astrid Bochow, Thomas G. Kirsch and Rijk van Dijk
}

Throughout history, people on the African continent have experienced momentous transformations of their lifeworlds and ways of living, some of them irruptive, uncompromising and cataclysmic, others of a more subtle and negotiable nature. What remains to be dealt with in more detail by anthropologists are the manifold ways in which these transformations are reflected in, and have a bearing on, people's ethical demeanours, commitments and debates. Given the complexity and variability of these processes, it is not possible or even desirable to give a conclusive answer to this question. Instead, taking account of historical and sociocultural specificities, this special issue features in-depth case studies of ethics as ideals in practice from several countries in sub-Saharan Africa (Botswana, Guinea Bissau, Kenya, South Africa and Tanzania). In doing so, the contributions combine a presentation of ethnographic findings with a discussion of a new conceptual approach for a practice-oriented anthropological study of 'ordinary ethics' (Lambek 2010).

In this introduction, we argue for a rather fluid notion of ethics that entails people's convictions, value judgements and sentiments on how to live a morally good and/or just life. We suggest that the making and unmaking of ethical fields takes place within the context of state politics, the influence of international organizations and the emergence of new publics and local NGOs that provide people with new ideas about what is 'right' and 'wrong'. We show that these ethical fields emerge in dialectical processes between what we call the 'implication' and 'explication' of ethics.

In what follows, we first briefly reflect on previous anthropological work on ethics in Africa. We then delineate the parameters of our conceptual approach, before finally commenting on how the articles in this special issue broaden our understanding of everyday struggles in contemporary Africa to achieve or to maintain a certain ethical composure, to win relevant others over to committing themselves to particular ethical principles, or to position oneself in relation to the (un)ethical claims of others.

\footnotetext{
Astrid Bochow is a social anthropologist at the Georg-August Universität Göttingen. She researches and publishes on the family, youth, religion and health in Kumasi, Ghana, and Gaborone, Botswana. Since September 2015 she has held a DFG-funded project grant on 'Social and Religious Activism: Health and Family in Law and Politics'. Email: a.bochow1@ gmail.com

Thomas G. Kirsch is Professor of Social and Cultural Anthropology at the University of Konstanz. He has published two books on African Christianity in Zambia and articles in some of the major refereed anthropology journals. Since 2003, he has conducted fieldwork on issues of security, crime prevention and volunteering in South Africa. Email: thomas.kirsch@uni-konstanz.de

Rijk van Dijk is a researcher at the African Studies Centre, Leiden, and Professor in the Study of Religion and Sexuality in Africa, University of Amsterdam. He co-edited The Quest for Fruition through Ngoma (2000) and The Social Life of Connectivity in Africa (2012). His current research is on Pentecostalism, consumerism and marriage in Botswana. Email: r.a.van.dijk@asc.leidenuniv.nl
}

(C) International African Institute 2017 


\section{The anthropology of ethics in Africa: a selective review}

Broadly speaking, in the history of anthropology, the study of ethics in the everyday lives of people in Africa has most prominently - but, for a long time, only implicitly - been associated with ethnographies of witchcraft. This is because the study of 'witchcraft' provides insights into how people conceptualize what it means to lead a morally 'good' life. Looking at this research allows us to critically position ourselves in relation to assumptions that are widely held in this field and have had some influence on how ethics in Africa have been interpreted.

Since the early work of Evans-Pritchard on the Azande (1937), studies of witchcraft in Africa from colonial times to the present have raised the issue of ethics by demonstrating the power of 'the danger from within': that is, the envy and malevolence emerging from within intricate circles of kin and family networks, from friends and neighbours. In this 'anthropology of evil' (Parkin 1985), over the decades the debate has increasingly drawn attention to processes through which ethics interact with change and transformations in the realms of the family, religion, economy and politics (Ashforth 2004; Geschiere 1997; 2013; Moore and Sanders 2001; Niehaus et al. 2001; ter Haar 2007), thus offering useful analytical tools for studying ethics as 'ideals in practice'.

One of the earlier high points in debates on ethics in African societies was Gluckman's (1972) seminal study of witchcraft accusations and witch hunts. According to him, the latter emerge in situations of a 'moral crisis' and in contexts of profound social and political change. ${ }^{1}$ With a view to colonial Africa, he argues that they were born out of the communal desire to reorder society and that, in giving public expression to convictions about how people should conduct themselves, they also espoused imaginaries about what society 'is' and how it is supposed to be.

As Csordas (1987) notes, ethically informed imaginaries of a reordered society like these inevitably go together with counter-imaginaries of evil, so that witchcraft accusations can be seen as exhibiting people's fundamental reasoning about humanness and human nature. This reasoning rests on evaluative ideas about 'good' and 'bad' and on people's moral assessment of personhood and agency. In other words, coming back to Gluckman's analysis, by suspecting and accusing others of enacting witchcraft, people allocate responsibility for what they perceive to be unwelcome transformations. Therefore, what Gluckman and others have pointed out is that witcheraft accusations are social processes that reflect on ongoing transformations and through which people actively reflect and negotiate ethical issues.

In strongly emphasizing the social reflexivity of this process, we disassociate ourselves from approaches which seem to suggest that the dialectic between 'ethics' and 'evil', as spelled out in certain Africanist debates on witcheraft, has an ontological basis and therefore in a way is unquestionably a given in - and

\footnotetext{
${ }^{1}$ The idea of a 'moral crisis' has also been influential for recent anthropological work on ethics. For instance, it has been taken up by Jarrett Zigon (2007) under the heading of 'moral breakdown'. For the conceptual differentiation between 'morality' and 'ethics' in this special issue, see below.
} 
'essential' to - Africa. ${ }^{2}$ Such essentializing notions need to be called into question for the manner in which they collapse the dialectics between imaginaries of the good and the counter-imaginaries of social evil on the one hand, and specific socio-cultural formations of witchcraft accusations in African societies on the other. We suggest that, in contrast to these approaches, and when seen from a historical and cultural comparative perspective, such dialectics can also be found elsewhere, so that the ethical predicaments of African witchcraft should be considered to be nothing more than a variation of a thoroughly transversal phenomenon.

\section{The changing subjects of ethics: the example of the study of religious life}

Studies of religious life in Africa have shown that religious ethics inform how people on the continent evaluate and make sense of crises, conflicts and the ever changing conditions of their lives. Also, in many classical ethnographic descriptions of African religious life, kin groups, villages, ethnic groups or communities of various sorts have been seen as engaging in collectively shared ethics. In other words, it has been assumed that the 'subjects of ethics' are collectivities that were most often depicted as bounded socio-cultural units striving towards social stability. Ritual performances were accordingly perceived as being conducted with the hope of instilling or reinstating social and/or cosmic order into the bodies, minds and souls of people or an entire community (cf. Durkheim 1912; for a critique, see Faubion 2011: 11).

Yet, as studies of social change in sub-Saharan Africa demonstrate, colonial and postcolonial institutions such as missions, schools and hospitals contributed to processes of religious change. This had far-reaching consequences for the ways in which ethics were translated into and made to interact with local discourses and practices. How did these transformations affect, firstly, who is seen to be addressed by religious ethics (in our terminology: the 'objects' of ethics)? And, secondly, who acts as and is perceived to be the 'subject' of ethics?

As has been pointed out repeatedly, in postcolonial African societies, religious ethics have been crucial for people coping with situations of poverty in years of structural adjustment (Gifford 2004). For example, the buzz phrase 'make a complete break with the past' (Meyer 1998) indicates an important aspect of Pentecostal identity in the 1990s. It describes how a radical turn against tradition, its authorities and ways of believing became intrinsic to people's changing ethical self-positioning in marginalized sections of African societies during these years. Yet, according to a number of studies in this field, Pentecostal ethics not only launched social harmony but in many cases did just the opposite: they served as spiritual weapons for protest and as ethical counter-narratives, often demanding radical changes in spiritual and socio-political matters as well (van Dijk 1992; Meyer 1998). Similarly, scholars have seen rituals of spirit possession as harbouring resistance or embodying the power of the marginalized (such as women in patriarchal societies or peasants resisting colonial power) in a context that otherwise does not allow for the verbal articulation of dissonant interests or dissident ethical commitments (see, for example, Comaroff 1985; Boddy 2002).

\footnotetext{
${ }^{2}$ See, for example, Vigh and Sausdal (2014) for a discussion of the recent 'ontological turn' in anthropology.
} 
Besides exemplifying how social transformations are related to the formulation of new ethical claims and contestations, the study of Pentecostalism in Africa also makes clear the ways in which religious ethics are moving from the sacred space of ritual performance into the mundane domain of daily life. For instance, Pentecostalism has been interpreted as introducing new consumer and entrepreneurial-oriented Protestant ethics into African societies (Gifford 2003; 2004). With their gospel of prosperity, Pentecostal churches equip their members with 'spiritual tools' to manage the forces they feel exposed to by Western lifestyles (Meyer 1999; van Binsbergen 2005). This shows that religious ethics have the potential to transform believers into global consumers and endow them with agency to adapt to the powers of neoliberalism in ways that allow them to proactively embrace these in an entrepreneurial mode of ethics (van Dijk 2010).

These examples highlight the fact that religious ethics can have powerful effects on the lives of people by either reproducing existing hierarchies or empowering people in distress. But they also indicate that, in the history of anthropological thought, there has been a shift in ethnographies of African societies from a focus on communal to more individualized forms of ethical commitments. Yet despite their differences, they all show how ethics are translated into social practice.

\section{Ethics, harmony and conflict: the example of the study of kinship}

When Gluckman's essay was published in 1972, the social units through which he and many of his contemporaries saw conflicts arising were ethnic groups, villages and, above all, kinship, which was widely seen as the basic unit of social organization at the time. Most aspects of social life - such as the selection of marriage partners, labour organization, political functions and the distribution of services and goods - were seen as being managed through an idiom of lineages and clans (Fortes 1957; 1975). In postcolonial societies, kin and families have likewise been shown to offer people support in times of crisis and in contexts of nonexistent or failing state welfare services (Whyte and Whyte 2004; Vaughan 2005; Mazzucato 2008). In many of these studies, family life has been described as being governed by an ethics of mutual care, support and respect. Yet, as Geschiere (2013) has stated, there is a danger of romanticizing family life in Africa. This, he argues, is highly problematic since the same social circles of intimate relationships among kin also often produce fears and anxieties, such as those related to witchcraft.

When seen in this light, it becomes clear that an analytical focus on the role of ethics in enabling harmonious relationships between kin needs to be supplemented with an awareness of the strained nature of kinship relations, which often culminates in ethical controversies between relatives, for instance when younger family members move from rural areas to towns and leave their elderly relatives without care (Livingston 2003; Ingstad 2004; van der Geest 2008; Cliggett 2005).

The anthropological study of ethics should thus remain critical of approaches that depict ethics as purely good and noble principles and values that inspire people and organizations in their everyday lives and foster harmony among them. Ethics can also be pressurizing, constraining and controversial, thus causing frictions between people who are otherwise connected to each other through intimate ties. 


\section{The implicitness/explicitness of ethics: the example of NGO-ization in Africa}

Noticeable at present on the African continent is a reconfiguration of the public sphere that finds expression in the emergence of new actors, organizations and forms of agency that locate themselves in - and act as intermediaries in the social space between - individuality and different forms of wider sociality. This process has been described by some scholars as a reorganization of Africa's civil society and, often as a consequence of a retrenchment of the nation state, as an NGO-ization of the public space. Yet, these actors and agencies do not go uncontested. Being placed under pressure to gain legitimacy in the wider social field, many of them take recourse to explicit ethical self-positionings. This process has led to a marked diversification of ethical claims in the public sphere.

Two connected processes can be noted here: the 'ordinarization' and 'extraordinarization' of ethics. Ordinarization describes the normalization of the ways in which new ethical codes become ingrained in everyday sociality. This process is contingent upon the rise of new institutional contexts and formations as well as the techniques that are available for conveying, establishing and managing the ethicalization of specific concerns. Extra-ordinarization involves ethical commitments being extrapolated from the tacit-ness of people's ordinary lives and made to play a role as expressly formulated points of concern, advocacy, conflict and/or contestation. As a consequence, ethical commitments that were previously tacit and implicit in everyday practices increasingly become objects of explicit reflection, commentary, negotiation and dispute, and thus become 'extraordinary' in their potential and significance.

The anthropological study of ethics has recently been enriched by inquiries into the rising number of organizations and social movements in Africa that are propagating ideas on how people should achieve or lead a good, prosperous, healthy and just life (cf. Robins 2006; Mutua 2009). In many cases, these organizations are supported by transnational institutions in their fight for human rights, health or human safety, and that provide the former with the information, training and financial means to found, for instance, new NGOs (Englund 2000; 2011). Broadly speaking, these organizations and social movements can be said to engage in processes through which ethical commitments are made both more explicit (by spelling them out publicly) and more implicit (in that they aim for a normalization of their respective ethics in people's everyday lives).

A number of these studies look at the connection between ethical claims and issues of governance. For example, certain codified discursive markers relating to ethics, such as 'humanity', 'survival' or 'security', have become central to transnational modes of governmentality in African politics and publics (cf. Fassin 2011). At the same time, in many of these studies, 'ethics' is used almost exclusively in the conceptual sense of a 'discourse' or 'ideology', here understood as a mode of governance pervading all aspects of life. The problem with most of these studies is that they predominantly focus on the process by which the ethical commitments promoted by new institutions are internalized and become implicit in people's lifeworlds, partially disabling reflection on and/or the critical questioning of the individual's own position. Such approaches thus run the risk of being blind to the processes through which ethics are made explicit in the first place. A rare example of the latter is Pnina Werbner's (2014) study on 
labour unions in Botswana. Examining the case of a labour union's political success in performing a strike in 1991, Werbner shows how the discursive recourse to the ethical principles of justice, fairness and giving voice to contenders, which had long been important in the judicial practices of local courts (kgotla), became crucial for the strike's public acceptability, despite the fact that strikes are legally forbidden by Botswana's constitution. In short, her case study shows how longstanding ethical principles turned into powerful argumentative weapons once they were explicitly introduced into public debate. This process of voicing one's ethical principles in the public domain is what we call the 'explication of ethics'.

In addition, studies like these exemplify that ethical claims can be an intricate part of - and a catalyst for - political changes in twenty-first-century Africa. Yet, in contexts like the ones mentioned above, ethics represent more than mere tools to be used for political manipulation or to attract resources. When ethical principles are made explicit in the public sphere, they can also question and decentre existing power relations, bringing about wider contestations, cleavages and societal conflicts.

The contributions in this special issue demonstrate that neither a focus on the implicitness of ethics, nor one on their explicitness, provides a full understanding of the dynamic interactions between processes of socio-cultural change and the (re)formulation of people's ethical commitments. Instead, they aim to explore the dialectics between the two. Doing so allows us to gain important insights into questions of governmentality, the emergence of new African publics, and accompanying societal conflicts.

\section{Analysing ethics as ideals in practice}

Present-day Africa, our contributors demonstrate, is transitional and fraught with uncertainties concerning future developments. The continent is internally diverse, not only because it is demographically heterogeneous but also because its populations socialize with each other in various ways. These points have important implications for an ethnographic investigation into the workings of ordinary ethics in Africa.

\section{An ethnographic approach to ethics}

What are ethics? And how can they be studied ethnographically? 'It does not harm that the notion [of the ethical] is vague,' argues moral philosopher Bernhard Williams (2011: 20). Thus, for Williams, the very fluidity of the notion of the ethical is useful when trying to come to an understanding of how ethics are practised in human life. In line with this argument, as well as with Michael Lambek's notion of 'ordinary ethics', we suggest that even the question of what is considered, in a given time and place, to fall under the category of 'the ethical' (and what is seen to lie outside it) is already part of ethical discourse and practice. Given our analytical approach to ethics as 'ideals in practice', a certain terminological and conceptual fluidity is essential in defining such a field, in order to examine ethnographically the translation of ethical ideals into the practicalities of everyday life.

The recently intensified interest in ethics benefits from earlier scholarship on morality, which originated in the work of Émile Durkheim (1912; see also 
Heintz 2009; Howell 1997; Zigon 2008). Broadly speaking, in our understanding of the difference between 'ethics' and 'morality' we follow Williams (2011: 10), who distinguishes the rather abstract nature of ethics from morality, which he describes as 'a specific system with clear cut boundaries' (ibid.). When seen in this light, the study of morality refers to specific and contextual values and meanings while ethics relate to overarching abstract principles through which people access and evaluate their own and other's actions and attitudes, such as 'humanity', 'justice' and 'freedom' (see also Mattingly 2012). In the contributions to this special issue, these overarching principles include 'care' (Vigh), 'security' (Kirsch), 'prestige' (van Dijk) and 'life as a value in and of itself' (Bochow).

Yet, ethical considerations, demeanours and expectations should not be conceived of as cool-headed and deliberate mental operations on preferred principles or courses of action. Rather, they usually appeal to a sense of urgency. In line with this idea, Williams proposes to revive the concept of 'virtue' as developed in enlightenment philosophy, which refers to 'characteristic patterns of desires and motivations' (Williams 2011: 10). Thus, ethics can be said to provoke strong feelings towards a particular issue or action taken. Several of our contributors attest to this. Urbanites in Botswana feel strongly about having children because they represent the continuation of life in a context of death (Bochow, this issue), for example, and drug dealers in Bissau are judged according to the ways in which they socially and emotionally provide for family members (Vigh, this issue). In this way, ethics 'catapult' (van Dijk 2010) people into action, after laying out potential trajectories for the manner in which ideas and imaginaries become social drivers.

In other words, in contrast to the more delimited scope of morality, ethics entail value judgements that - in principle, if not always in practice - are of a socially encompassing nature, such as the premise that all human beings deserve to be secure (Kirsch, this issue) or the idea that the poor should be helped (Dilger, this issue). This means that ethical assumptions have wider implications for how people imagine social life per se and are principally thought to be applicable to everyone irrespective of, for example, age, gender, social status or religious orientation.

It is the latter premise that also distinguishes 'ethics' from 'ideology' in the materialist tradition or from 'discourse' in Foucauldian approaches. Ideologies and discourses are part and parcel of social configurations characterized by marked inequalities, different forms of exploitation, and modes of governmentality in which institutionalized mental constructs (Comaroff and Comaroff 1991) come to be perceived as 'natural' even by those who suffer most from being structurally subdued by them. It is true that, as we noted above, certain ethical commitments can also be supportive of exploitative conditions. Yet, when examining ethics as ideals in practice, this observation should not always or necessarily be the starting point of our analysis. Instead, we need to recognize that ethical claims are predicated on the paradigmatic idea of human equality. They are thought of as applying to everyone, even if, when put into practice, they often bring about social differentiations of one kind or another. The Protestant ethic, for example, 'disqualifies' people in the eyes of God if they do not work hard enough; yet the ethical premise that Christians should show their dedication to God by working hard is believed to hold true for everyone. Taking this into consideration allows us to do justice to the socially encompassing aspirations of those 
with certain ethical commitments, without summarily and prematurely presuming their motivations for doing so to be grounded in sectional interests.

A question needs to be raised, however, about the existence of an all-human nature, which has lately been dismissed by authors promoting the so-called 'ontological turn', such as Viviero de Castro (2004; for a critique of the latter position, see Vigh and Sausdal 2014). Our contributors all start from the assumption that conceptualizing ethics as encompassing value judgements does not presuppose the analytical premise of the empirical existence of a universal human nature. Instead, they show that, by making ethical claims in social practice, this notion of an all-human nature is performatively brought into being.

This perspective raises interesting questions about the changing social scale of ethical claims on the African continent. Several of the contributions in this special issue therefore take account of processes of translation from one socio-cultural context to another. Thus, of particular relevance for the topic of this special issue is ethnographic work that shows how universalist ethical claims, such as human rights, are reinterpreted and transformed when translated into the sociocultural specificities of African localities (cf. Goodale and Merry 2007; Merry 2006; for Africa cf. Wilson 2006).

\section{The subjects of ethics}

We suggest that the anthropological study of ethics should be pursued, firstly, in the form of an ethnographic inquiry into what is emically assumed - at a particular time and place, by the people under investigation - to constitute the 'subjects of ethics'. Are ethics considered to be located in individuals or in a given social group, whatever its specific type or characteristics? Max Weber's (1934) classic writings on the Protestant ethic, alongside more recent research on individuating discourses of ethical (self-)responsibilization, provide examples of the former. ${ }^{3}$ On the other hand, if ethics are said to be nested within a particular social grouping, which collective identifications, membership categories, interaction routines and institutional logics have an influence on how the respective ethical commitments are defined and enacted? By taking account of such emic assumptions, we avoid widespread presuppositions in social theory, such as the idea that individuals are the 'natural' locus of ethics, as proclaimed in Aristotelian ethics, or that the subjects of ethics are characterized by some given and fixed social 'groupness' (cf. Brubaker 2002). Instead, this approach allows the historically and culturally manifested role of ethics in the constitution of subjectivities and socialities in Africa to be determined.

Take the example of $u b u n t u$, a term in the Nguni language cluster that came to prominence in public debates on the feasibility, conditionality and desirability of an 'African renaissance' (cf. Bongmba 2004; Maloka 2001) in post-apartheid South Africa, and which has variously been interpreted to represent a world view, a philosophy, an ideology, or - most importantly for our argument here an ethical 'affirmation of one's humanity through recognition of an "other" in his or her uniqueness and difference' (Eze 2010: 190). What is at issue in these

\footnotetext{
${ }^{3}$ See, for example, van Dijk (2013) on the practice of 'counselling' in Africa in which this has become a forceful trajectory.
} 
debates is not just the meanings and characteristics of ubuntu, it is also the question of who can be said to be its subjects. Some reserve this term for 'black' South Africans who are said to be enculturated in this form of ethical commitment by default. Others speak out in favour of a non-racialized use of this term, affirming that ubuntu can be practised by people from all sections of South African society, 'white' no less than 'black', making it the ethical foundation of an all-encompassing post-apartheid nation building.

Our contributors analyse who can be considered to be such subjects, as they emerge in a particular ethical field, by portraying self-positionings and struggles over competing claims. These subjects range from religious groups and individual religious practitioners (Bochow, this issue; Dilger, this issue), through volunteers (Kirsch, this issue) and drug dealers (Vigh, this issue) to the new professional classes (Parkin, this issue; van Dijk, this issue).

\section{The objects of ethics}

Secondly, research on ordinary ethics in Africa should pay attention to the 'objects of ethics': that is, to those material realities, persons, attitudes and 'doings and sayings' (Schatzki 1996) to which its subjects, as defined above, practically direct their respective ethical commitments. This directedness can be introverted and self-referential, finding expression in, for example, ethical self-discipline or acts of mutual surveillance within a community of ethics, say a Pentecostal church. But it can also be extroverted and made valid for others as well - sometimes by force - as among hegemonic Islamist forces in West Africa. In both cases, the pertinent question concerning the objects of ethics is: who or what in particular is the practical addressee of a given ethical practice?

Coming back to ubuntu, the question of who in particular should benefit from other people's ethical commitment to it is much contested in South Africa. There is a clear understanding by many that 'criminals' ought not to be dealt with gently but should be exempted from the mildness and leniency usually associated with ubuntu (see Hornberger 2011). Similarly, the xenophobic attacks against immigrants from other African countries in 2008 and thereafter make it clear that many who in principle feel committed to the ethical premises of ubuntu in practice do not treat everybody according to these premises. In these cases, the universalizing potential of ethics is narrowed down by excluding certain groups of people, thus transforming ethics into situational and context-specific morality in practice. However, one also finds cases where these ethical premises are applied intentionally not in a selective and exclusivist way but rather in a problematically inclusive gesture of encompassment. In a highly controversial article published some years ago, medical anthropologist Suzanne Leclerc-Madlala documented the attitudes of South African university students to unprotected sex in the era of HIV/ AIDS, pointing out that some of her interlocutors provocatively 'evoked the word $u$ buntu when talking about why they would want to infect others with the virus if they themselves became infected' (Leclerc-Madlala 1997: 371).

Given our definition of ethics as overarching abstract principles, putting ethics into practice thus necessarily involves translating socially encompassing aspirations to the specificities of local situations and contexts. In this process, universalist ethical claims are practically scaled down and made to focus on very specific people or organizations to whom ethical claims are directed and who are turned into 'objects of ethics' through this process. 
Two case studies in this issue - one on a charity event at a religious school in Tanzania (Dilger) and the other on healing rituals of Islamic healers in Kenya (Parkin) - demonstrate how people's ethics as ideals in practice bring about specific objects of ethics, such as orphans deserving charity (Dilger) and patients seeking medical advice (Parkin). In a similar vein, the ethics of care as pursued by male youth in urban Guinea Bissau are directed towards their relatives and therefore represent an important motivation for them to enter the precarious drug trade (Vigh). However, objects of ethics do not necessarily remain stable over a long period of time. Instead, their specific qualities, composition and delimitation are often rendered problematic in social negotiations and contestations, partly because those sections of society who are targeted as objects by the ethical claims of others do not always or necessarily acquiesce to being ascribed this role, as Bochow argues for HIV policies and education in Botswana. Similarly, Kirsch demonstrates that the claims by volunteers in the field of civic crime prevention that they protect their neighbours is at times expressly contested by the very people they claim to serve. On the other hand, van Dijk shows that ethics have a certain elasticity, in that people can contest them without denying or altogether rejecting them.

\section{'Ethical stuff', boundary work and ethical dilemmas}

The 'contents' of ethical claims and commitments are not the primary focus of this special issue. Although it is unquestionably worthwhile to study such 'contents', our contributors follow a different track. They take inspiration from Fredrik Barth's work on ethnicity, which is concerned less with the 'cultural stuff' (Barth 1969: 15) mobilized to establish, maintain or contest ethnic boundaries than with ethnic boundary making itself. In an analogous fashion, they do not attempt to gather up and probe in detail the 'ethical stuff' to which specific groups of people subscribe. Instead, they emphasize the fact that ethical claims and commitments can and are being used by actors to constitute, negotiate, consolidate or challenge the social and/or institutional boundaries delimiting (selfprofessed) communities of ethics. It is the exploration of how boundaries shift between different subjects of ethics, as well as between the subjects of ethics and their respective objects, which is their primary concern.

Such processes at times create situations in which ethical claims and ethical practice fail to match. In contrast to classical traditions of moral philosophy, which take such dilemmas as an indication of a fundamental loss of identity and hence agency - in an ethically fragmented world, our contributors are interested in people's reactions to and reformulations of individual and institutional agency when confronted with ethical dilemmas. These reformulations concern the question of what it means to 'do good', 'lead a better life' or 'make a difference'.

Dilemmas like these are characteristic of the religious educational landscape in urban Tanzania, where teachers may perform religious rituals in the context of their work (such as common prayers) while personally belonging to a different denomination from the one operating the school (Dilger, this issue). Or, in the case of HIV education in Botswana discussed by Bochow, people may adhere to messages of safe sex and yet at the same time engage in unprotected sexual intercourse in order to fulfil their aspirations to have children. Among traditional 
healers in Kenya (Parkin, this issue), seemingly irreconcilable ethics can be shown to operate alongside each other, such as the medical ethics of healing and the religiously inspired ethics of care. Moreover, as van Dijk notes, conflicts over competing ethical claims are sometimes allowed a certain level of convivial elasticity rather than being pushed to the extremes of contention: ethical dilemmas seem to live tacitly just beneath the surface.

\section{Cleavages and alliances in 'ethical fields'}

In combining the analytical foci outlined above, we are taking account of the fact that ethics as ideals are always relational in social practice. At first sight, there is nothing surprising about the idea that ethics are part of social relationships. However, this does not necessarily imply a clear-cut correlation between a specific set of ethical commitments on the one hand, and a particular group of people on the other. Instead, there are dynamic interplays between different ethical claims and commitments that only sometimes conflict. At times they are brought into situational alliances despite being positioned as mutually incompatible at other times and in other contexts.

In order to understand how these dynamics play out within what we call 'ethical fields', a term loosely adopted from Bourdieu's (1991) 'religious field', let us look at another of Gluckman's classic studies. In his 'Analysis of a social situation' (1958 [1940]), he examined the variety of social actors present at the ceremonial opening of a bridge in colonial South Africa, which allowed him to analyse the structured relationships between subsections of the 'white' and 'black' population and to show the existence of a number of cross-cutting cleavages and alliances. Among those attending the event was 'a group of Christian Zulu [who stand] in close relationship with some Whites, and [which therefore] represents a sphere of Zulu-White co-operation' (ibid.: 61). At the same time, however, 'all Christian Zulu are closely associated with pagan Zulu in many ways, and they get no equality with Whites in or outside Churches' (ibid.). What follows from this is a social configuration of great complexity which is worth quoting at some length:

Some Zulu Christians, affected by this [experience of inequality], react against White Christianity. If they revert simply to Zulu paganism they are not structurally opposed to the Zulu-White Christian group; they are opposed only to the White Christian group. Therefore the groups opposed to Zulu-White Christians embrace some Christian beliefs and are free of White control: but their beliefs must be different from, as well as similar to, Zulu-White Christian beliefs, and usually pagan beliefs are used to express this opposition. In turn these pagan beliefs enable dissident Zulu Christians to associate with pagan Zulu in ways in which White-church Zulu cannot, while they can associate with church Zulu as pagan Zulu cannot. (ibid.: 61-2)

If we replace 'belief' with 'ordinary ethics', we can see how a similar logic of crosscutting cleavages and alliances is characteristic of ethical fields in present-day Africa. In these fields, ethical claims and commitments serve as registers of language and action that are employed by people when perceiving, making sense of and evaluating the social realities they are confronted with, as well as when attributing a specific ethical value to them. Further, by drawing on them in context-dependent ways, use of these registers can help establish connections or disconnections between different subjects and socialities. 
The contours and characteristics of ethical fields on the African continent have undergone momentous changes in recent decades, owing to societal challenges brought forth by large-scale violent conflicts; rising concerns about the failure of political systems, inequalities, corruption and human rights; natural disasters and epidemics such as the HIV/AIDS pandemic; the appearance of new transnational actors and agencies; people's increased connectivity and mobility made possible by innovations in the fields of media and technological infrastructure; and the rapidly advancing diversification of lifestyles and life opportunities. No less than a transformation of previous decades and centuries, these processes of change, our contributors show, are leading to the emergence of new ethical fields as well as to the reconfiguration of existing ones.

That people are struggling with their respective ethical commitments not only has to do with the contingencies of life, or the fact that ethics as ideals of practice can never be identical with how they are practised in reality. It also results from the messy, multifaceted and often inconsistent nature of the transformations referred to above. The dynamics within ethical fields as well as between them are characterized by a 'mutual contest of sameness and difference on a stage characterised by radical disjunctures between different sorts of ... flows and the uncertain landscapes created in and through these disjunctures' (Appadurai 1990: 308).

Within different ethical fields in Africa - whether relating to international interventions, nation-state formation or human rights - processes of the explication and implication of ethics are evident. In addition, each ethical field brings forth a particular 'cultivation' of that field by the respective subjects of ethics. Yet, the overlaps and disjunctures of ethical fields within a given social context mean not only that the social location of the ethical subject has become much more complex (if not confusing) than before, but also that the ethical 'labour' that individuals and communities are required to perform has become more exacting, more demanding and more controversial. This is because, in contemporary Africa, the emergence of 'ordinary ethics' as ideals in practice that belong to a lived-in world of experience, cognition and sentiment can no longer be taken for granted. Instead, the making and unmaking of ethical fields reflect, among many other things, ongoing transformations of religious landscapes and kinship structures as well as the reworking of human rights-related judicial systems and people's attempts to cope with massive insecurities, inequalities and violence (Kirsch 2010). While the particular ways of cultivating ethical fields, as discussed in the case studies in this special issue, can be said to be uniquely African, they are also transversally informative of the underlying processes of ethical formations in general and the ways in which new social locations of ethical subjects come about.

\section{Acknowledgements}

The contributions to this special issue were first presented during a workshop at the Centre for Advanced Studies at the University of Konstanz and then again at a roundtable discussion, sponsored by the International African Institute (IAI), at the 2015 ECAS conference in Paris. We thank the Centre of Excellence at the University of Konstanz for its financial support and the IAI for coordinating the event at the ECAS conference. We would also like to cordially thank Michael Lambek for his inspiring comments on our papers in Paris. 


\section{References}

Appadurai, A. (1990) 'Disjuncture and difference in the global cultural economy', Theory, Culture and Society 7 (2): 295-310.

Ashforth, A. (2004) Witchcraft, Violence, and Democracy in South Africa. Chicago IL and London: University of Chicago Press.

Barth, F. (1969) Ethnic Groups and Boundaries: the social organization of culture difference. Oslo: Universitetsforlaget.

Boddy, J. (2002) 'Social value, embodiment, and gender practice in Northern Sudan' in S. Ellingson and C. Green (eds), Religion and Sexuality in Crosscultural Perspective. New York NY: Routledge.

Bongmba, E. K. (2004) 'Reflections on Thabo Mbeki's African renaissance', Journal of Southern African Studies 30 (2): 291-316.

Bourdieu, P. (1991) 'Genesis and structure of the religious field', Comparative Social Research 13: 1-44.

Brubaker, R. (2002) 'Ethnicity without groups', European Journal of Sociology 43 (2): $163-89$.

Cliggett, L. (2005) Grains from Grass: aging, gender, and famine in rural Africa. New York NY: Cornell University Press.

Comaroff, J. (1985) Body of Power, Spirit of Resistance: the culture and history of a South African people. Chicago IL: University of Chicago Press.

Comaroff, J. and J. L. Comaroff (1991) Of Revelation and Revolution. Vol. 1: Christianity, colonialism, and consciousness in South Africa. Chicago IL: University of Chicago Press.

Csordas, T. J. (1987) 'Genre, motive, and metaphor: conditions for creativity in ritual language', Cultural Anthropology 2 (4): 445-69.

Durkheim, E. (1912) The Elementary Forms of the Religious Life. London: George Allen and Unwin.

Englund, H. (2000) 'The dead hand of human rights: contrasting Christianities in post-transition Malawi', Journal of Modern African Studies 38 (4): 579-603.

Englund, H. (2011) Human Rights and African Airwaves: mediating equality on the Chichewa radio. Bloomington IN: Indiana University Press.

Evans-Pritchard, E. E. (1937) Witchcraft, Oracles and Magic among the Azande. London: Oxford University Press.

Eze, M. O. (2010) Intellectual History in Contemporary South Africa. New York NY: Palgrave Macmillan.

Fassin, D. (2011) Humanitarian Reason: a moral history of the present. Berkeley CA: University of California Press.

Faubion, J. D. (2011) An Anthropology of Ethics. Cambridge: Cambridge University Press.

Fortes, M. (1957) The Web of Kinship among the Tallensi. London: Oxford University Press.

Fortes, M. (1975) 'Kinship and marriage among the Ashanti' in A. R. RadcliffeBrown and D. Forde (eds), Systems of African Kinship and Marriage. London: Oxford University Press.

Geschiere, P. (1997) The Modernity of Witchcraft: politics and the occult in postcolonial Africa. Charlottesville VA: University of Virginia.

Geschiere, P. (2013) Witchcraft, Intimacy, and Trust: Africa in comparison. Chicago IL: University of Chicago Press. 
Gifford, P. (2003) '2000 years: looking backwards and forwards' in P. Gifford, D. Archard, T. A. Hart and N. Rapport (eds), 2000 Years and Beyond. London and New York NY: Routledge.

Gifford, P. (2004) Ghana's New Christianity: Pentecostalism in a globalising African economy. Bloomington IN: University of Indiana Press.

Gluckman, M. (1958 [1940]) 'Analysis of a social situation in modern Zululand', The Rhodes Papers 28 (special issue).

Gluckman, M. (1972) The Allocation of Responsibility. Manchester: Manchester University Press.

Goodale, M. and S. E. Merry (2007) The Practice of Human Rights: tracking law between the global and the local. Cambridge: Cambridge University Press.

Heintz, M. (2009) The Anthropology of Moralities. Oxford: Berghahn.

Hornberger, A. (2011) 'The withdrawal of the gods: remarks on ritual trancepossession and its decline in Bali' in M. Picard and R. Martin (eds), The Politics of Religion in Indonesia. London: Routledge.

Howell, S. (1997) The Ethnography of Moralities. London: Routledge.

Ingstad, B. (2004) 'The value of grandchildren: changing relations between generations in Botswana', Africa 74 (1): 62-75.

Kirsch, T. G. (2010) 'Violence in the name of democracy: community policing, vigilante action and nation-building in South Africa' in T. G. Kirsch and T. Grätz (eds), Domesticating Vigilantism in Africa. Oxford: James Currey.

Lambek, M. (2010) Ordinary Ethics: anthropology, language, and action. New York NY: Fordham University Press.

Leclerc-Madlala, S. (1997) 'Infect one, infect all: Zulu youth response to the AIDS epidemic in South Africa', Medical Anthropology 17 (4): 363-80.

Livingston, J. (2003) 'Reconfiguring old age: elderly women and concerns over care in Southeastern Botswana', Medical Anthropology 22 (3): 205-31.

Maloka, E. T. (2001) 'The South African "African renaissance" debate: a critique', Polis 8: 9-18.

Mattingly, C. (2012) 'Two virtue ethics and the anthropology of morality', Anthropological Theory 12 (2): 161-84.

Mazzucato, V. (2008) 'Transnational reciprocity: Ghanaian migrants and the care of their parents at home' in E. Alber, S. van der Geest and S. R. Whyte (eds), Generations in Africa: contrasts and connections. Hamburg: LIT.

Merry, S. E. (2006) 'Transnational human rights and local activism: mapping the middle', American Anthropologist 108 (1): 38-51.

Meyer, B. (1998) "“Make a complete break with the past": memory and postcolonial modernity in Ghanaian Pentecostalist discourse', Journal of Religion in Africa 28 (3): 316-49.

Meyer, B. (1999) 'Commodities and the power of prayer: Pentecostalist attitudes towards consumption in contemporary Ghana' in B. Meyer and P. Geschiere (eds), Globalization and Identity: dialectics of flow and closure. Oxford: Blackwell.

Moore, H. L. and T. Sanders (2001) Magical Interpretations, Material Realities: modernity, witchcraft and the occult in postcolonial Africa. London: Routledge.

Mutua, M. (2009) Human rights NGOs in East Africa: political and normative tensions. Philadelphia PA: University of Pennsylvania Press.

Niehaus, I. A., E. Mohlala and K. Shokane (2001) Witchcraft, Power, and Politics: exploring the occult in the South African Lowveld. Cape Town: David Philip. 
Parkin, D. J. (1985) The Anthropology of Evil. London: Blackwell.

Robins, S. (2006) 'From "rights" to "ritual": AIDS activism in South Africa', American Anthropologist 108 (2): 273-461.

Schatzki, T. R. (1996) Social Practices: a Wittgensteinian approach to human activity and the social. Cambridge: Cambridge University Press.

ter Haar, G. (2007) Imagining Evil: witchcraft beliefs and accusations in contemporary Africa. Trenton NJ: Africa World Press.

van Binsbergen, W. M. J. (2005) 'Commodification: things, agency, and identities. Introduction' in W. M. J. van Binsbergen and P. L. Geschiere (eds), Commodification: things, agency, and identities. Hamburg: LIT.

van der Geest, S. (2008) 'Wisdom and intergenerational gift? Notes from KwahuTafo, Ghana' in E. Alber, S. van der Geest and S. R. Whyte (eds), Generations in Africa: contrasts and connections. Hamburg: LIT.

van Dijk, R. (1992) 'Young puritan preachers in post-independence Malawi', Africa 62 (2): 159-81.

van Dijk, R. (2010) 'Social catapulting and the spirit of entrepreneurialism: migrants, private initiative, and the Pentecostal ethic in Botswana' in K. Krause and G. Hüwelmeier (eds), Traveling Spirits: migrants, markets and mobilities. New York NY and London: Routledge.

van Dijk, R. (2013) 'Counselling and Pentecostal modalities of social engineering of relationships in Botswana', Culture, Health and Sexuality 15 (S4): 509-22.

Vaughan, M. (2005) 'Which family? Problems in the reconstruction of the history of the family as an economic and cultural unit' in A. Cornwall (ed.), Readings in Gender in Africa. Bloomington IN: Indiana University Press.

Vigh, H. E. and D. B. Sausdal (2014) 'From essence back to existence: anthropology beyond the ontological turn', Anthropological Theory 14 (1): 49-73.

Viviero de Castro, E. B. (2004) 'Exchanging perspectives: the transformation of objects into subjects in Amerindian ontologies', Common Knowledge 10 (3): 463-84.

Weber, M. (1934) 'Die protestantische Ethik und der Geist des Kapitalismus' in M. Weber (ed.), Gesammelte Aufsätze zur Religionssoziologie I. Tübingen: J. C. B. Mohr.

Werbner, P. (2014) “The duty to act fairly": ethics, legal anthropology, and labor justice in the Manual Workers Union of Botswana', Comparative Studies in Society and History 56 (2): 479-507.

Whyte, S. R. and M. A. Whyte (2004) 'Children's children: time and relatedness in Eastern Uganda', Africa 74 (1): 76-94.

Williams, B. (2011) Ethics and the Limits of Philosophy. London: Taylor \& Francis.

Wilson, R. A. (2006) 'Afterword to "Anthropology and human rights in a new key": the social life of human rights', American Anthropologist 108 (1): 77-83.

Zigon, J. (2007) 'Moral breakdown and the ethical demand: a theoretical framework for an anthropology of moralities', Anthropological Theory 7 (2): 131-50.

Zigon, J. (2008) Morality: an anthropological perspective. Oxford: Berg. 